\title{
Review Article \\ Chinese Herbal Medicine on Dyslipidemia: Progress and Perspective
}

\author{
Ming Guo, ${ }^{1,2}$ Yue Liu, ${ }^{1,2}$ Zhu-Ye Gao, ${ }^{1,2}$ and Da-zhuo Shi ${ }^{1,2}$ \\ ${ }^{1}$ Cardiovascular Diseases Center, Xiyuan Hospital, China Academy of Chinese Medical Sciences, Beijing 100091, China \\ ${ }^{2}$ China Heart Institute of Chinese Medicine, China Academy of Chinese Medical Sciences, Beijing 100091, China \\ Correspondence should be addressed to Da-zhuo Shi; shidazhuo@126.com
}

Received 1 December 2013; Accepted 6 January 2014; Published 13 February 2014

Academic Editor: Waris Qidwai

Copyright (c) 2014 Ming Guo et al. This is an open access article distributed under the Creative Commons Attribution License, which permits unrestricted use, distribution, and reproduction in any medium, provided the original work is properly cited.

\begin{abstract}
Dyslipidemia is an independent risk factor of cardiovascular diseases. The statins are a milestone in the primary and second prevention of cardiovascular diseases and significantly improved its prognosis. Along with the long-term treatment with statins in combination with other hypolipidemic drugs or alone, its safety has attracted a particular attention in clinic, such as the elevation of transaminase and rhabdomyolysis, which have raised an idea of developing the other types of lipid-lowering agents from botanic materials. Traditional Chinese medicine (TCM) has been used in clinical practice for more than 2000 years in China and showed some beneficial effects for human health and many diseases. Recently, many studies demonstrated a favorable effect of TCM for treating dyslipidemia; however, its mechanism remains unclear or totally unknown. The progress and perspective of studies on dyslipidemia with single Chinese herb and its monomers or effective extracts during the past 10 years are discussed in the present review.
\end{abstract}

\section{Introduction}

Dyslipidemia is characterized by elevated level of total cholesterol (TC), triglyceride (TG), and low-density lipoprotein cholesterol (LDL-C) and by lowered level of high-density lipoprotein cholesterol (HDL-C) in serum. Dyslipidemia is one of the major independent risk factors for coronary heart disease (CHD) and stroke [1]. The "2013 ACC/AHA Guideline on the Treatment of Blood Cholesterol to Reduce Atherosclerotic Cardiovascular Risk in Adults" emphasized that the progressively regulating dyslipidemia is the pivotal controlling method for risk factors of ischemic cardiovascular events [2]. A large number of evidence indicated that the statins (3-hydroxy-3-methyl-glutaryl-coenzyme reductase inhibitor) significantly reduce the morbidity and mortality of cardiovascular and cerebrovascular events, such as MI and stroke [3]. Along with a long-term use of statins in combination with other hypolipidemic drugs or alone, however, its safety has attached a great concern from scientists and researchers, such as transaminase and creatinine elevation, skeletal muscle pain, and creatine kinase elevation. Therefore, developing novel classes of hypolipidemic agents which possess high efficiency and fewer adverse effects has still been a focus on the treatment of dyslipidemia.

Although the hyperlipidemia has not been used in traditional Chinese medicine (TCM) term, patients with hyperlipidemia exhibited the similar etiology and pathological changes which charactered as phlegm, dampness, and blood stasis in TCM theory. Moreover, accumulating evidence has indicated that the TCM could improve phlegm, dampness, and blood stasis syndromes manifested in patients with hyperlipidemia even exhibit a beneficial effect for lowering hyperlipidemia $[4,5]$. Due to the complicated mechanism of TCM on lipid lowering, most researches currently focus their attention on the effects of Chinese herb monomer or effective extracts in hyperlipidemia (see Figure 1). Studies show that the following Chinese herbs possess a favorable effect on hyperlipidemia to extent degree, which might be classified into four categories: (1) clearing heat and removing 
<smiles>Cc1nc(C)c(C)nc1C</smiles>

Ligustrazine<smiles>Cc1coc2c1C(=O)C(=O)c1c-2ccc2c1CCCC2(C)C</smiles>

Tanshinone IIA

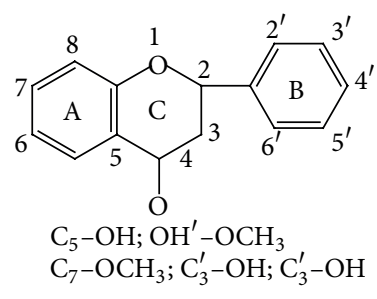

Hawthorn leaves flavonoids<smiles>Oc1ccc(/C=C/c2cc(O)cc(O)c2)cc1</smiles><smiles>COc1ccc2cc3[n+](cc2c1OC)CCc1cc2c(cc1-3)OCO2</smiles><smiles>COc1cc(/C=C/C(=O)CC(=O)/C=C/c2ccc(O)c(OC)c2)ccc1O</smiles>

Resveratrol

Berberine

Curcumin<smiles>O=C(O)C1OC2(O)Oc3c(cc4oc(-c5ccccc5)cc(=O)c4c3O)OC1C(O)C(O)C2O</smiles>

Scutellaria Baicalensis stem-leaf total flavonoid<smiles>O=c1c(-c2ccc(O)cc2)coc2c(C3O[C@H](CO)[C@@H](O)C(O)[C@H]3O)c(O)ccc12</smiles><smiles>O=C(O)C1CC(O)C2C(O)C3C(O)CCCC3C(O)C2C1</smiles>

Rhein<smiles>Cc1cc(O)c2c(c1)C(=O)c1cc(O)cc(O)c1C2=O</smiles>

Frangula emodin

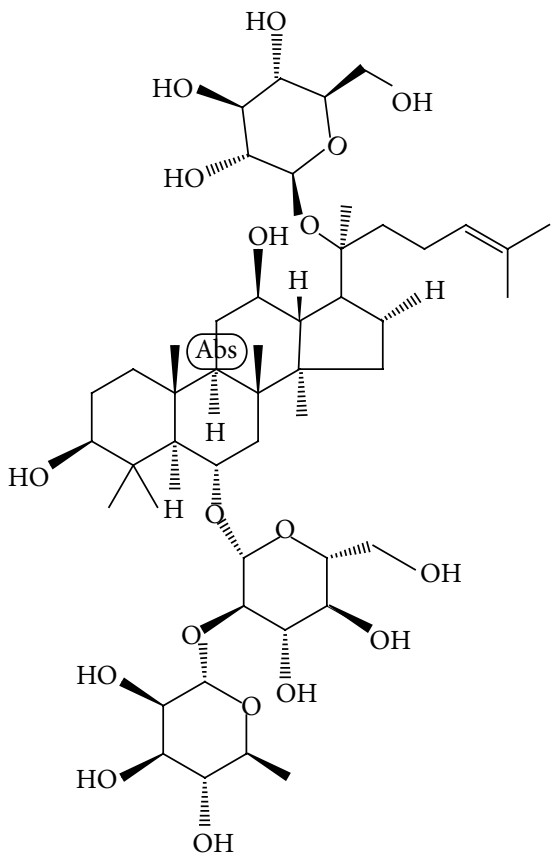

Ginsenosides

FIgURE 1: Chemical structures of effective components of Chinese herbs for dyslipidemia. 
toxicity, for example, Radix et Rhizoma Rhei, Rhizoma polygoni cuspidati, Semen Cassia, Coptis chinensis, Scutellaria baicalensis, Gynostemma pentaphyllum, and Radix Puerariae; (2) promoting blood circulation and removing blood stasis, for example, Fructus crataegi, Red yeast rice, Rhizoma, Radix salvia miltiorrhizae, and Turmerone; (3) eliminating dampness and phlegm, for example, Rhizoma alismatis, Plantain seed, and folium nelumbinis; (4) tonifying energy of body (including "Qi," kidney), for example, Radix Astragali, Radix Ginseng, and Radix polygoni multiflori (see Table 1). In present review, we summarized the clinical and experimental studies of single Chinese medicine and its monomers or effective extracts on dyslipidemia published during the recent 10 years.

\section{Single Chinese Herb and Its Monomers or Extracts}

2.1. Rheum officinale ( $\mathrm{Da}$ Huang). Radix et. Rhizoma Rhei is derived from the root and rhizome of Rheum palmatum Linn. (Polygonaceae), Rheum tanguticum Maxim. Ex Balf. (Polygonaceae), or Rheum officinale Baill (Polygonaceae). It is used to purge fire, to remove stagnation by purgation, to cool the blood, to remove toxins, and to remove blood stasis. Anthraquinones, a main active component of Rhubarb, including rhein, aloeemodin, emodin, chrysophanol, and physcion, exhibited lipid-lowering roles by promoting intestinal peristalsis and inhibiting the intestinal absorption of cholesterol [6]. Gao et al. found that rhein, at an oral dosage of $150 \mathrm{mg} / \mathrm{kg} /$ day for 12 weeks, was proved to be lowering serum TG, TC, and LDL-c levels in $\mathrm{db} / \mathrm{db}$ mice with diabetic nephropathy [7]. The powders of rhubarb administrated, at $5 \mathrm{~g}$ /day orally for 24 weeks, decreased serum TG and TC levels in patients with diabetic nephropathy [8]. Danthron is another extract of rhubarb, study showing that, at $0.1 \mu \mathrm{mol} / \mathrm{L}, 1 \mu \mathrm{mol} / \mathrm{L}$, and $10 \mu \mathrm{mol} / \mathrm{L}$ of culture medium, dose-dependently promoted the phosphorylation of Adenosine monophosphate activated protein kinase (AMPK) and acetyl-CoA carboxylase (ACC) in both HepG2 and C2C12 cells. Likewise, danthron significantly reduced sterol regulatory element-binding protein 1c (SREBP1c) synthesis and fatty acid synthetase (FAS) gene expressions; both were closed to the lipid metabolism [9]. In addition, Li and Liu found that the powders of rhubarb administrated at $9 \mathrm{~g} /$ day for 5 days in 30 health volunteers caused some side-effects, such as vomiting, headache, diarrhea, and abdominal pain [10]. You reported that the decoction boiled from rhubarb, for example, at $8 \mathrm{~g}, 16 \mathrm{~g}$ and $32 \mathrm{~g} / \mathrm{kg} /$ day for 5 days in mice, caused fatty degeneration of hepatic cell [11].

\subsection{Polygonum cuspidatum (Hu Zhang). Polygonum cuspi-} datum (PC) is derived from the dried root and rhizome of Polygonum cuspidatum Sieb. et Zucc. It dispels wing dampness, removes stagnation, relieves pain, and reduces phlegm. Polydatin and resveratrol, the primary active components of PC, inhibited the cholesterol absorption from intestinal tract [12]. Du et al. found that polydatin administrated at oral dosages of $25 \mathrm{mg}, 50 \mathrm{mg}$, and $150 \mathrm{mg} / \mathrm{kg} / \mathrm{day}$ for $15-$ 21 days significantly decreased TC, TG, and LDL-c levels and increased TC/HDL-c ratio in hyperlipidemic hamsters and rabbits $[12,13]$. Park et al. reported that the Polygonum cuspidatum water extract (PCWE) at $5 \mathrm{ug} / \mathrm{mL}$ and $40 \mathrm{ug} / \mathrm{mL}$ of culture medium reduced the cholesteryl ester formation in human hepatocytes by inhibiting A-cholesterol acyltransferase activity (ACAT) in HepG2 cell in vitro, and PCWE at the $40 \mathrm{ug} / \mathrm{mL}$ inhibited ACAT activity by $50 \%$ [14]. Resveratrol administrated at oral dosages of $30 \mathrm{mg}$ and $70 \mathrm{mg} / \mathrm{kg} /$ day for 4 weeks significantly lowered serum lipid, hepatic cholesterol (TC), and TG levels and accelerated the excretion of bile acids in hyperlipidemic rats [15]. In addition, Tong had a case report [16] showing that the oral decoction boiled containing $30 \mathrm{~g}$ PC caused gastrointestinal adverse reaction.

2.3. Semen Cassia (Jue Ming Zi). Semen Cassia is the ripe seed of Senna obtusifolia Linn. (Fabaceae) or Cassia tora Linn. (Leguminosae). It clears away the liver fire to improve eyesight and moistens the intestines to relax the bowels. Proteins and anthraquinone glycosides, the active components of Semen Cassiae, displayed a hypolipidemic effect, mainly due to inhibiting cholesterol absorption, synthesis, and HMG-CoA reductase expression [17]. Lin and Xiong found that the extracts from Semen Cassia administrated at oral dosages of $8 \mathrm{mg}, 15 \mathrm{mg}$, and $25 \mathrm{mg} / \mathrm{kg} /$ day for 35 days significantly decreased TC, TG, and LDL-c and increased HDL-c in hyperlipidemic rats [18]. Li et al. showed that the administration with extracts from Semen Cassia for 1week, at $180 \mathrm{mg} / \mathrm{kg} /$ day, significantly decreased the levels of TC, TG, and LDL-c in the mice injected intraperitoneally with $75 \%$ fresh yelkfluid [19]. Luo et al. documented that the administration with the total anthraquinone from Semen Cassia, at oral dosages of $0.1 \mathrm{~g}, 0.2 \mathrm{~g}$, and $0.4 \mathrm{~g} / \mathrm{kg}$ for 2 months, remarkably reduced the serum concentration of TC, TG in Sprague Dawley (SD) rats administrated with alcohol, at $12.5 \mathrm{~mL} / \mathrm{kg}$ for the $1 \mathrm{st}$ month and $11.25 \mathrm{~mL} / \mathrm{kg}$ for the $2 \mathrm{nd}$ and 3rd month for 2 times a day, for 3 months [20]. Zou and Li suggested that the anthraquinone, Semen Cassiae should be used cautiously because of its potential toxicity [21].

2.4. Rhizoma Coptidis (Huang Lian). Rhizoma Coptidis (RC) is derived from the dried root and rhizome of Coptis chinensis Franch., Coptis deltoidea C. Y. Cheng et Hsiao, and Coptis teeta Wall. It has the role of clearing away heat, eliminating dampness, purging fire, and removing toxin. Its main components include alkaloid and lignans. Among the alkaloids, the alkaloid berberine is an active component for lipid lowering. Zhou et al. found that berberine administrated, at oral dosages of $75 \mathrm{mg}, 150 \mathrm{mg}$, and $300 \mathrm{mg} / \mathrm{kg} / \mathrm{day}$ for 16 weeks, had a favorable effect in lowering serum TG, TC, and LDL-c and increasing HDL-c [22]. Chang et al. demonstrated that berberine injected intraperitoneally at $200 \mathrm{mg} / \mathrm{kg} /$ day for 16 weeks significantly decreased the serum TC, LDL-c levels and hepatic cholesterol in male SD rats treated with high-fat diet (HFD) for 8 weeks and also upregulated LDLR mRNA expression and suppressed HMGR 
TABLE 1: The most frequently used single Chinese herbs for dyslipidemia.

\begin{tabular}{|c|c|c|c|c|c|}
\hline Number & Herbs & Dosage/administration/time & Effects & Components & References \\
\hline 1 & $\begin{array}{l}\text { Rheum officinale } \\
\text { (Da Huang) }\end{array}$ & $\begin{array}{l}\text { Human: powder, } 5 \text { g/day, Po, } 24 \text { weeks; Db/db mice: } \\
\text { rhein, } 150 \text { m/kg/day, Po, } 12 \text { weeks }\end{array}$ & $\mathrm{TG} \downarrow \mathrm{TC} \downarrow$ LDL-C$\downarrow$ & Anthraquinones & {$[7,8]$} \\
\hline 2 & $\begin{array}{l}\text { Rhizoma ploygoni } \\
\text { cuspidate } \\
\text { (Hu Zhang) }\end{array}$ & $\begin{array}{c}\text { Rabbits: polydatin, } 25 \mathrm{mg}, 50 \mathrm{mg}, 100 \mathrm{mg} / \mathrm{kg} / \text { day Po, } \\
3 \text { weeks; SD rats: resveratrol 30, } 70 \mathrm{mg} / \mathrm{kg} \text { Po, } \\
4 \text { weeks }\end{array}$ & $\mathrm{TG} \downarrow \mathrm{TC} \downarrow$ LDL-C $\downarrow$ & $\begin{array}{l}\text { Polydatin, } \\
\text { resveratrol, and } \\
\text { emodin }\end{array}$ & {$[12,13,15]$} \\
\hline 3 & $\begin{array}{l}\text { Semen Cassia } \\
\quad \text { (Jumingzi) }\end{array}$ & $\begin{array}{l}\text { SD rats: extracts, } 8,15,25 \mathrm{mg} / \mathrm{kg} \text { Po, } 35 \text { days; } \mathrm{SD} \\
\text { rats: anthraquinones, 0.1, 0.2, 0.4 g/kg Po, } 2 \text { months }\end{array}$ & $\mathrm{TG} \downarrow \mathrm{TC} \downarrow$ LDL-C $\downarrow$ & $\begin{array}{l}\text { Anthraquinones, } \\
\text { protein }\end{array}$ & {$[18,20]$} \\
\hline 4 & $\begin{array}{l}\text { Coptis chinensis } \\
\text { (Huanglian) }\end{array}$ & $\begin{array}{c}\text { Human: berberine, } 500 \mathrm{mg} \text { tid Po, } 12 \text { weeks; SD rats: } \\
\text { berberine, } 200 \mathrm{mg} / \mathrm{kg} / \mathrm{day} \text { ip, } 16 \text { weeks; SD rats: } \\
\text { berberine } 75 \mathrm{mg}, 150 \mathrm{mg}, 300 \mathrm{mg} / \mathrm{kg} / \text { day po } \\
16 \text { weeks }\end{array}$ & $\begin{array}{c}\mathrm{TC} \downarrow \mathrm{LDL}-\mathrm{C} \downarrow \mathrm{TG} \downarrow \\
\mathrm{HDL}-\mathrm{c} \uparrow\end{array}$ & Alkaloid berberine & {$[22-24]$} \\
\hline 5 & $\begin{array}{l}\text { Scutellaria } \\
\text { baicalensis } \\
\text { (Huangqin) }\end{array}$ & SD rats: SSTF, $75 \mathrm{mg}, 150 \mathrm{mg} / \mathrm{kg}$ Po, 25 days; & $\begin{array}{c}\mathrm{TC} \downarrow \mathrm{LDL}-\mathrm{C} \downarrow \mathrm{TG} \downarrow \\
\mathrm{HDL}-\mathrm{c} \uparrow\end{array}$ & Flavonoid & {$[25]$} \\
\hline 6 & $\begin{array}{l}\text { Gynostemma } \\
\text { pentaphylla } \\
\text { (Jiaogulan) }\end{array}$ & $\begin{array}{l}\text { Mice: powder, } 250 \mathrm{mg} / \mathrm{kg}, \text { Po, } 4 \text {-day; SD rats: } \\
\text { extract, } 50 \mathrm{mg}, 200 \mathrm{mg} / \mathrm{kg} / \mathrm{day} \text {, Po, } 4 \text { weeks }\end{array}$ & $\mathrm{TG} \downarrow \mathrm{TC} \downarrow \mathrm{LDL}-\mathrm{C} \downarrow$ & Gypenoside & {$[26,27]$} \\
\hline 7 & $\begin{array}{l}\text { Radix Puerariae } \\
\text { (Gegen) }\end{array}$ & $\begin{array}{l}\text { Wistar rats: puerarin, } 50 \mathrm{mg} / \mathrm{kg} / \mathrm{day} \text { ip, } 30 \text { days; } \\
\text { ovariectomized rats: flavones, } 100 \mathrm{mg} / \mathrm{kg} / \text { day, po, } \\
5 \text { weeks }\end{array}$ & $\begin{array}{c}\mathrm{TC} \downarrow \mathrm{LDL}-\mathrm{C} \downarrow \mathrm{TG} \downarrow \\
\mathrm{HDL}-\mathrm{c} \uparrow\end{array}$ & Puerarin & {$[28,29]$} \\
\hline 8 & $\begin{array}{l}\text { Fructus crataegi } \\
\quad \text { (Shan zha) }\end{array}$ & $\begin{array}{l}\text { Human: aqueous extracts, } 3.6 \mathrm{~g} / \mathrm{kg}, \mathrm{Po}, 3 \text { months; } \\
\text { rats: ethanol extracts, } 30 \mathrm{mg}, 100 \mathrm{mg} / \mathrm{kg} / \text { day. Po., } \\
4 \text { weeks }\end{array}$ & $\mathrm{TG} \downarrow \mathrm{TC} \downarrow \mathrm{LDL}-\mathrm{C} \downarrow$ & $\begin{array}{l}\text { Flavonoids, } \\
\text { triterpenic acids }\end{array}$ & {$[30,31]$} \\
\hline 9 & $\begin{array}{l}\text { Red yeast rice } \\
\text { (Hongqu) }\end{array}$ & $\begin{array}{l}\text { Human: rice, } 600 \mathrm{mg} / \text { day, Po, } 8 \text { weeks; human: rice, } \\
1.2 \mathrm{mg} \text {, po, } 6 \text { months }-1 \text { year }\end{array}$ & $\mathrm{TC} \downarrow$ LDL-C $\downarrow$ TG $\downarrow$ & $\begin{array}{l}\text { Lovastatin, sterols, } \\
\text { Isoflavones and } \\
\text { isoflavone glycosides, } \\
\text { and MUFA }\end{array}$ & {$[32,33]$} \\
\hline 10 & $\begin{array}{l}\text { Rhizoma } \\
\text { chuanxiong }\end{array}$ & $\begin{array}{c}\text { Rats: ligustrazine, } 20 \mathrm{mg}, 80 \mathrm{mg} / \mathrm{kg} \text {, Po, } 6 \text { weeks; } \\
\text { rabbits: ligustrazine, } 75 \mathrm{mg}, 150 \mathrm{mg} / \mathrm{kg} / \text { day, Po, } \\
12 \text { weeks }\end{array}$ & $\mathrm{TG} \downarrow \mathrm{TC} \downarrow \mathrm{LDL}-\mathrm{C} \downarrow$ & $\begin{array}{l}\text { Lactones, total } \\
\text { alkaloids }\end{array}$ & {$[34,35]$} \\
\hline 11 & $\begin{array}{l}\text { Radix salvia } \\
\text { miltiorrhizae } \\
\text { (Danshen) }\end{array}$ & $\begin{array}{l}\text { Rats: extracts, 50, 100, } 150 \mathrm{mg} / \mathrm{kg} / \text { day, Po, } 4 \text { weeks; } \\
\text { human: tanshinone IIA, } 80 \mathrm{mg} / \text { day, ivgtt. } 14 \text { days }\end{array}$ & $\begin{array}{c}\mathrm{TC} \downarrow \mathrm{LDL}-\mathrm{C} \downarrow \mathrm{TG} \downarrow \\
\mathrm{HDL}-\mathrm{c} \uparrow\end{array}$ & Tanshinone IIA & {$[36,37]$} \\
\hline 12 & $\begin{array}{l}\text { Turmerone } \\
\text { (Jianghuang) }\end{array}$ & $\begin{array}{l}\text { Hamsters: curcumin, } 0.05 \text { g/100 g, Po, } 10 \text { weeks; SD } \\
\text { rats: curcumin, 40, 80,160 mg/kg, Po, } 4 \text { weeks }\end{array}$ & $\begin{array}{l}\mathrm{TC} \downarrow \mathrm{LDL}-\mathrm{C} \downarrow \mathrm{TG} \downarrow \\
\mathrm{FFA} \downarrow \text { HDL-c } \uparrow\end{array}$ & Curcumin & {$[38,39]$} \\
\hline 13 & $\begin{array}{l}\text { Rhizoma alismatis } \\
\text { (Zexie) }\end{array}$ & $\begin{array}{l}\text { Human: powders, } 10 \mathrm{~g} / \text { day, Po, } 2 \text { weeks; SD rats: } \\
\text { extracts, } 0.3 \mathrm{~mL} / \text { day, Po, } 21 \text { days }\end{array}$ & $\mathrm{TC} \downarrow \mathrm{LDL}-\mathrm{C} \downarrow \mathrm{TG} \downarrow$ & Triterpenes & {$[40,41]$} \\
\hline 14 & $\begin{array}{c}\text { Plantain seed } \\
\text { (Cheqianzi) }\end{array}$ & $\begin{array}{l}\text { Human: polysaccharides, } 14 \text { g/day, Po, } 8 \text { weeks; rats: } \\
\text { powder, } 15 \mathrm{~g} / \mathrm{kg}, \text { Po, } 12 \text { weeks; pig: plantain seed, } 7.5 \text {, } \\
\qquad 10 \mathrm{~g} / 100 \mathrm{mg} \text {, po, } 4 \text { weeks }\end{array}$ & $\mathrm{TC} \downarrow \mathrm{LDL}-\mathrm{C} \downarrow \mathrm{TG} \downarrow$ & Polysaccharides & [42-44] \\
\hline 15 & $\begin{array}{l}\text { Folium nelumbinis } \\
\qquad \text { (Heye) }\end{array}$ & $\begin{array}{c}\text { SD rats: aqueous extracts, } 400 \mathrm{mg} / \mathrm{kg} / \mathrm{day}, \mathrm{Po} \text {, } \\
6 \text { weeks; mice: flavonoids, } 50,200 \mathrm{mg} / \mathrm{kg} / \mathrm{day}, \mathrm{Po} \text {, } \\
28 \text { days }\end{array}$ & $\mathrm{TC} \downarrow$ LDL-C $\downarrow$ TG $\downarrow$ & $\begin{array}{l}\text { Total flavonoids, } \\
\text { alkaloid }\end{array}$ & {$[45,46]$} \\
\hline 16 & $\begin{array}{l}\text { Radix Astragali } \\
\text { (Huangqi) }\end{array}$ & $\begin{array}{c}\text { Rat: extracts, } 0.4 \%, 0.8 \%, \text { Po, } 5 \text { weeks; rat: } \\
\text { polysaccharides, } 40,100 \mathrm{mg} / \mathrm{kg} / \text { day, Po, } 40 \text { days }\end{array}$ & $\begin{array}{l}\text { TC } \downarrow \text { LDL-C } \downarrow \text { TG } \downarrow \\
\text { HDL-c } \uparrow\end{array}$ & $\begin{array}{l}\text { Polysaccharides, } \\
\text { flavonoid, and } \\
\text { saponin }\end{array}$ & {$[47,48]$} \\
\hline 17 & $\begin{array}{l}\text { Radix Ginseng } \\
\text { (Renshen) }\end{array}$ & $\begin{array}{l}\text { Mice: ginsenoside, } 2 \mathrm{mg} / \mathrm{kg} / \text { days, Po, } 90 \text { days; rats: } \\
\text { ginsenoside } \mathrm{Rb}, 50 \mathrm{mg}, 100 \mathrm{mg}, 200 \mathrm{mg} / \mathrm{kg} / \mathrm{day}, \text { Po, } \\
12 \text { days }\end{array}$ & $\begin{array}{l}\text { TC } \downarrow \text { LDL-C } \downarrow \text { TG } \downarrow \\
\text { HDL-c } \uparrow\end{array}$ & $\begin{array}{l}\text { Ginsenoside, } \\
\text { ginseng, and } \\
\text { polysaccharides }\end{array}$ & {$[49,50]$} \\
\hline 18 & $\begin{array}{l}\text { Radix Polygoni } \\
\text { Multiflori } \\
\text { (Heshouwu) }\end{array}$ & $\begin{array}{l}\text { Rats: extracts, } 12,24 \mathrm{mg} / \mathrm{kg} / \text { day, Po, } 4 \text { weeks; rats: } \\
\text { EAEF, } 30,60 \mathrm{mg} / \mathrm{kg} / \text { day, Po, } 28 \text { days }\end{array}$ & $\begin{array}{l}\text { TC } \downarrow \text { LDL-C } \downarrow \text { TG } \downarrow \\
\text { HDL-c } \uparrow\end{array}$ & $\begin{array}{l}\text { Anthraquinones, } \\
\text { polysaccharides }\end{array}$ & {$[51,52]$} \\
\hline
\end{tabular}


gene expression [23]. Hu et al. found that Caucasian obese human subjects were given $500 \mathrm{mg}$ berberine orally 3 times a day for 12 weeks showing that the blood lipid was significantly reduced and triglyceride and cholesterol were decreased by $23 \%$ and $12.2 \%$, respectively [24]. A meta-analysis concerning 11 randomized controlled trials and 874 participants showed that the berberine produced a significant reduction in TC, TG, and LDL-c [53]. In addition, Zhang et al. reported that berberine at more than $4 \mathrm{~g}$ (overdose) resulted in some adverse reactions, such as drug eruption, allergic reactions, dizziness, and shock [54].

\subsection{Scutellaria baicalensis (Huang Qin). Scutellaria baicalen-} sis is derived from the dried root of Scutellaria baicalensis Georgi. It clears away heat, eliminates dampness, purges fire, removes toxin, and stops bleeding. Flavonoid compound is an effective lipid-lowering component in Scutellaria baicalensis [55]. Liu et al. found that Scutellaria baicalensis stem-leaf total flavonoids (SSTF) administrated at oral dosages of $75 \mathrm{mg}$, $150 \mathrm{mg} / \mathrm{kg} /$ day for 25 days in type 2 diabetic rats with hyperlipidemia significantly reduced the serum TG, TC, and LDL-c levels and increased HDL-c [25]. 0.05\% Scutellaria baicalensis radix extract was added to the diet in hyperlipidemia rats for 4 weeks, showing decrease of TG and TC of the bioflavonoids group [56]. SSTF was administrated at oral dosages of $25 \mathrm{mg}$, $50 \mathrm{mg}$, and $100 \mathrm{mg} / \mathrm{kg} /$ day in hyperlipidemia rats for 20 days, indicating that SSTF significantly reduced the serum TC, TG, and LDL-c levels and increased HDL-c and the activity of lecithin cholesterol acyltransferase (LCAT) [57].

2.6. Gynostemma Pentaphylla (Jiao Gu Lan). Gynostemma Pentaphylla (GP) is derived from the dried root and rhizome of Gynostemma pentaphyllum (Thunb.) Makino. It clears away heat, removes toxin, relieves cough, and eliminates phlegm. Gypenoside is an active component of GP [58]. Studies have found that the lipid-lowering effect of GP was related to inhibiting fat cells producing free fatty acid and synthesizing neutral fat $[26,59,60]$. GP administrated at oral dosages of $250 \mathrm{mg} / \mathrm{kg}$ for 4 days significantly reduced TC (by 33\%), TG (by 13\%), and LDL-c (by 33\%) in the obese Zucker fatty diabetic rat model [26]. Zhou et al. established the hyperglycemia rat model with high-fat diet for 6 weeks and then treated them with high dose $(200 \mathrm{mg} / \mathrm{kg} /$ day $)$ or low dose $(50 \mathrm{mg} / \mathrm{kg} /$ day) of GP for 4 weeks and founded that GP could decrease the concentration of serum LDL-c, TC, and TG levels remarkably and raise the concentration of HDL-c [27].

2.7. Radix Puerariae (Ge Gen). Radix Puerariae is the dried root of Pueraria lobata (Willd.) Ohwi. (Fabaceae). It clears away heat, purges fire, and removes toxin in the theory of Compendium of Materia Medica. Isoflavone is the active compound of Kudzuvine root, such as puerarin, isoflavoues aglycone, daidzin [61]. Yan et al. found that puerarin administrated at oral dosages of $300 \mathrm{mg} / \mathrm{kg} /$ day for 4 weeks significantly reduced the serum and hepatic cholesterol levels of hyperlipidemia rats [62]. Experimental hyperlipidemia rats were injected intraperitoneally puerarin (50 mg/kg/day) for
30 days, showing that the plasma TG, TC, and LDL-c significantly reduced and HDL-c increased [28]. Furthermore, oral administration of Kudzuvine root flavones at $100 \mathrm{mg} / \mathrm{kg} /$ day for 5 days was reported to enhance hepatic lipid metabolism in ovariectomized rats [29]. Patients with puerarin injections may cause certain adverse effects, such as allergic responses, bloody stool, and backache [63].

2.8. Fructus Crataegi (Shan Zha). Fructus crataegi (FC) is derived from the dried mature fruit of Crataegus pinnatifida Bunge. var. major N.E.Br. (Rosaceae) or Crataegus pinnatifida Bunge. (Rosaceae). FC is used to dissipate food accumulation, to improve blood circulation, and to disperse blood stasis. Flavonoids and triterpenic acids are the main active hypolipidemic components of FC [64]. FC aqueous extracts given at an oral dosage of $3.6 \mathrm{~g} /$ day for 3 months were demonstrated to lower blood TC, TG, and LDL-c in 45 hyperlipidemic volunteers [30]. 80\% ethanolic extract administrated at oral dosages of $30,100 \mathrm{mg} / \mathrm{kg} /$ day for 4 weeks in hyperlipidemic rats markedly reversed the increased plasma TC and HDL-c levels [31]. A study on mice that were fed with high-fat diets following the oral administration of FC extracts at a dosage of $250 \mathrm{mg} / \mathrm{kg} /$ day for 7 days in vivo indicated that FC's lipidlowering action may be related to increased levels of liver PPAR $\alpha[65]$.

2.9. Fermentum Rubrum (Red Yeast Rice). Fermentum Rubrum, popularly known as red yeast rice (RYR) which is the fermented product of Monascus purpureus on rice. It is composed of 13 kinds of natural statins, unsaturated fatty acids, ergosterol, amino acids, flavonoids, alkaloid, trace element, and so forth. 79 patients with baseline LDL-c level of $5.28 \mathrm{mmol} / \mathrm{L}$ received a twice daily dose of red yeast rice $(600 \mathrm{mg})$ for 8 weeks in a randomized, double-blind, placebo-controlled study, which found that this therapy could reduce LDL-c by $27.7 \%$, TG by $21.5 \%$, and TC by $15.8 \%$ [32]. 72 patients with idiopathic persistent nephritic syndrome with secondary dyslipidemia were randomly given Monascus purpureus Went rice at $600 \mathrm{mg}$ twice one day orally, which significantly reduced serum cholesterol after 6 months and 1 year [33]. XueZhiKang capsule is the extract of red yeast rice. In china, scholars made a systematic review on the clinical randomized controlled trials for treating hyperlipidemia with Xuezhikang, which included 22 randomized trials and a total of 6520 participants, and showed that xuezhikang remarkably lowered TC, TG, and LDL-C compared with theinositol nicotinate [66]. Animal safety evaluations indicate that RYR does not cause any toxic effects in albino rats [67]. However, dyslipidemia patients treated with RYR (1200 mg/day) experienced a few nonserious side effects, such as heartburn, flatulence, dizziness, and gastrointestinal discomfort [63].

2.10. Rhizoma Chuanxiong (Chuang Xiong). Rhizoma chuanxiong $(\mathrm{RC})$ is the dried rhizome of Ligusticum chuanxiong Hort. (Umbelliferae). It promotes blood and qi circulation, expels wind, and alleviates pain.

RC contains a variety of esters and alkaloids. Ligustrazine in RC plays an important role in contributing to 
hypolipidemic effects of RC [68]. Ligustrazine given at an oral dosage of $20 \mathrm{mg}, 80 \mathrm{mg} / \mathrm{kg} /$ day in atherosclerosis rats decreased TG levels (by $65.2 \%$ and $76.7 \%$ ), TC (by $53.2 \%$ and $77.9 \%$ ), and LDL-c (by $71.2 \%$ and 79\%) levels [34]. Tetramethylpyrazine administered at $75 \mathrm{mg}, 150 \mathrm{mg} / \mathrm{kg} / \mathrm{day}$ for 12 weeks in atherosclerosis rabbits, significantly reduced the serum TC, TG, and LDL-c levels [35]. The oral administration of RC causes headaches and injection of ligustrazine can also cause bleeding and allergic responses in certain cases [69].

2.11. Radix Salviae Miltiorrhizae (Dan Shen). Radix Salviae Miltiorrhizae (RSM) is derived from the root and rhizome of Salvia miltiorrhiza Bge. (Lamiaceae). It removes blood stasis and promotes blood circulation, relieves pain, regulates menstruation, removes heat from the heart, and relieve restlessness. Dan Shen is widely used to treat patients with coronary artery disease in China. Tanshinone is the main effective component in RSM [70]. Aqueous extracts of RSM given at oral dosages of $50 \mathrm{mg}, 100 \mathrm{mg}$, and $150 \mathrm{mg} / \mathrm{kg} /$ day for 4 weeks significantly decreased TC and TG levels and increased HDL$\mathrm{C}$ serum levels in hyperlipidemic rats [36]. Tanshinone IIA (T-IIA) sulfonate intravenous injected $(80 \mathrm{mg}$ dissolved in $250 \mathrm{~mL} 0.9 \%$ salt water) at $80 \mathrm{mg} /$ day for 14 days in patients with diabetes mellitus decreased the serum TG, TC, and LDLc obviously [37]. In addition, human HepG2 cells treated with T-IIA for $24 \mathrm{~h}$ exerted a dose-dependent inhibitory effect on ApoB secretion together with triglyceride [71]. RSM may cause abdominal discomfort following long-term administration and also results in internal tissue bleeding when used in combination with aspirin or warfarin [72].

\subsection{Rhizoma Curcumae Longae (Jiang Huang). Rhizoma} curcumae longae (RCL) is derived from the root and rhizome of Curcuma longa L. It removes blood stasis, promotes the circulation of $\mathrm{Qi}$, regulates menstruation, and relieves pain. Curcumin is the main component in RCL [73]. Curcumin $(0.05 \mathrm{~g} / 100 \mathrm{~g}$ diet $)$ supplementation on a high-fat diet $(10 \%$ coconut oil, $0.2 \%$ cholesterol, wt/wt) fed to hamsters for 10 weeks significantly lowered the levels of free fatty acid (FFA), TG, TC, and LDL-c and elevated the levels of HDL$\mathrm{c}$ and apolipoprotein (apo) A-I and paraoxonase activity in plasma [38]. Curcumin administrated at dosages of $40 \mathrm{mg}$, $80 \mathrm{mg}$, and $160 \mathrm{mg} / \mathrm{kg} /$ day for 4 weeks in hyperlipidemia rats significantly reduced the serum and hepatic TC, TG, and FFA and increased the HDL-c [39]. In vitro, curcumin at $5 \mathrm{uM}$ concentration completely prevented $\mathrm{LDL}$ oxidation by $\mathrm{CuSO}_{4}$ [74]. The curcumin acting on the low density lipoprotein receptor (LDLR) expression which is measured by FluoMicroscopy and Fluorescence Flow Cytometric Methods in HepG2 cell obviously upregulated the expression of LDLR [75].

2.13. Rhizoma Alismatis (Ze Xie). Rhizoma alismatis (RA) is derived from the dried stem tuber of Alisma orientale (Sam.) Juzep. (Alismataceae). RA promotes diuresis to resolve dampness and expel heat. Triterpenes are the main active components from RA, which exerts its hypolipidemic effects by inhibiting the absorption and synthesis of cholesterol and improving lipid metabolism [76]. The powders of RA administered at oral dosages of $10 \mathrm{~g} /$ day for 2 weeks in healthy volunteers reduced the TC, LDL-C, and TG [40]. The oral administration of aqueous and alcoholic RA extracts at $0.3 \mathrm{~mL} /$ day for 21 days resulted in significant decreasing in serum TG, and TC, while increased the HDL-c and improved the artheriosclerosis index (AI) in hyperlipidemia SD rats [41]. The adverse effects of RA are correlated with hepatotoxicity following over dosage [42].

2.14. Semen Plantaginis (Che Qian Zi). Semen plantaginis is the ripe seed of Plantago asiatica L. or Plantago depressa Willd. Semen plantaginis clears heat, causes dieresis, excretes dampness, improves eyesight, and eliminates phlegm. The polysaccharides of Semen plantaginis (PSP) not only have the aperients effect but also the lipid-lowering role [77]. In a multicenter, double-blind, placebo-controlled, parallel, and randomized trial conducted in primary care-clinics in Spain, France, and Holland, mild-moderate hypercholesterolaemic patients (age range: 43-68 years) received $14 \mathrm{~g} / \mathrm{d}$ of the soluble fibre Plantago ovate (PO)-husk $(n=126)$ for 8 weeks. Pohusk reduced plasma LDL-C by $-6 \%$, total cholesterol (TC) by $-6 \%$, triglycerides (TG) by $-21.6 \%$, and apolipoprotein (Apo) B-100 by $-6.7 \%$ [78]. Wang et al. found that Plantain seed at dosage of $15 \mathrm{~g} / \mathrm{kg}$ for 12 weeks can decrease content of lipid and strengthen superoxide dismutase (SOD) activity [43]. Plantain seed administered at oral dosages of $7.5 \mathrm{~g}$, $10 \mathrm{~g} / 100 \mathrm{~g}$ for 4-weeks in male Hartley guinea pig significantly reduced the level of TC and LDL-c [44].

2.15. Folium Nelumbinis ( $\mathrm{He}$ Ye). Folium Nelumbinis is the dried leaf of Nelumbo nucifera Gaertn. It is used to clear away summerheat, to lift the lucid yang, to cool the blood, and to stop bleeding. The total alkaloids and flavonoids in Lotus leaves are the main active components of $\mathrm{He} \mathrm{Ye}$ [79]. Aqueous extracts of Lotus leaves administered at an oral dosage of $400 \mathrm{mg} / \mathrm{kg} /$ day for 6 weeks were demonstrated to lower serum TC, TG, and LDL-C levels in rats fed a highfat diet [45]. The flavonoids extracts of Lotus $(50 \mathrm{mg}$ and $200 \mathrm{mg} / \mathrm{kg}$ ) were orally administered once a day for 28 days in rats, showing that the serum TC, TG, and LDL-c levels were significantly decreased, whereas serum HDL-c level was increased [46]. As demonstrated in the livers of mice that were fed high-fat diets, the mechanisms of action of Lotus leaves may be associated with suppressed expression of FAS, acetyl-CoA carboxylase, and HMG-CoA reductase and the increased phosphorylation of AMP-activated protein kinase [47].

2.16. Radix Astragali (Huang Qi). Radix Astragali is the dried root of Astragalus propinquus (Fisch.) Bge. var. mongholicus (Bge.) Hsiao (Fabaceae) or Astragalus membranaceus (Fish.) Bge. (Fabaceae). It replenishes the qi to consolidate superficies and promotes diuresis to relieve edema. MMR polysaccharides, flavonoids, and sponins are the main active components of membranous milkvetch root (MMR) [48]. Astragalus Mongholicus extracts at $0.4 \%$ and $0.8 \%$ for 5 weeks in rats maintained on a high-cholesterol diet significantly 
reduced the serum of TG, TC, and LDL-c levels and increased the HDL-c levels and reduced levels of lipid peroxidation [80]. Polysaccharides from Astragalus administered at an oral dosage of $40 \mathrm{mg}, 100 \mathrm{mg} / \mathrm{kg} /$ day in hyperlipidemia rats for 40 days obviously reduced the serum TC, TG, LDLc, and MDA levels and increased HDL-c levels [81]. The hypolipidemic mechanisms of MMR polysaccharides in vivo may be associated with the increased expression of LDLR and 7-hydroxylase mRNAs and the decreased expression of HMG-CoA reductase mRNA in the liver [82]. The injection of Radix Astragali may cause nausea and allergic response [83].

2.17. Radix Ginseng (Ren Shen). Radix Ginseng is derived from the dried root and rhizome of Panax ginseng C.A. Mey. (Araliaceae). It reinforces vital energy, restores the pulse, treats exhaustion, reinforces the spleen to benefit the lungs, promotes the production of body fluids, and calms the mind. Ginseng saponins and polysaccharides are the main active components of Radix Ginseng [84]. Ginseng saponins intragastric administered at an oral dosage of $2 \mathrm{mg} / \mathrm{kg} / \mathrm{day}$ for 90 days in C57/BL-ApoE gene knockout hyperlipidemia rats can reduce the levels of plasma TC, TG, and LDL-c [49]. Ginseng saponin is divided into Rb1, Rb2, RC, Rd, Re, and $\mathrm{Rl}$ [85]. Ginseng saponin $\mathrm{Rb}$ administered at an oral dosage of $50 \mathrm{mg}, 100 \mathrm{mg}$, and $200 \mathrm{mg} / \mathrm{kg} /$ day in hyperlipidemia rat for 12 days significantly reduced the TG, TC, and LDL-c levels in serum and liver [50]. In addition, Compound $\mathrm{k}$ (CK) is a major intestinal metabolite of ginsenosides derived from ginseng radix. In vitro, CK significantly activated the AMP-activated protein kinase (AMPK) to affect the lipid metabolism in insulin-esistant HepG2 human hepatoma cells [86]. Ginseng saponins have poor bioavailability following oral administration. Although Ginseng is very safe for oral administration, an overdose or long-term administration of Ginseng may cause the neurotoxicity, cardiotoxicity or allergic reaction [69].

2.18. Radix Polygoni Multiflori (He Shou Wu). Radix Polygoni Multiflori (RPM) is derived from the dried root tuber of Fallopia multiflora Thunb. (Polygonaceae). RPM has been used in both raw and prepared pharmaceutical forms. Raw RPM prevents the recurrence of malaria, eliminates toxic materials, moistens the intestine, and relaxes the bowels. Prepared RPM blackens the hair and beard, strengthens the muscles and bones, improves the essence of the blood, and nourishes the liver and kidneys. RPM exerts its hypolipidemic effects primarily by targeting the gastrointestinal tract and inhibiting the absorption of cholesterol [87]. RPM extract administered at an oral dosage of $12 \mathrm{mg}$ and $24 \mathrm{mg} / \mathrm{kg} / \mathrm{day}$ for 4 weeks in hyperlipidemic rats reduced the serum levels of TC, TG, and LDL-c [51]. Wang et al. found the ethl acetate extracting fraction (EAEF) and stilbene glycoside from the tube of Polygonum multiflorum administered orally at dose of 30 and $60 \mathrm{mg} / \mathrm{kg} /$ day for 28 days could reduce the serum TC, TG, and LDL-c levels in hyperlipidemia rats [52]. As demonstrated in experiments with Bel-7402 cells, stilbene glucoside may be a key active component of RPM and involved in both inhibiting cholesterol synthesis and increasing the expression of low-density lipoprotein receptor (LDLR) mRNA [88]. Li et al. found that RPM extracts could regulate the lipid content within liver cell better than RPMP (Radix Polygoni Multiflori Praeparata), but RPMP displayed better effects than RPM in lipid regulation in the circulatory system [89]. Clinical reports have revealed that RPM exhibits hepatotoxicity, allergic responses, and gastrointestinal hemorrhage following chronic treatment $[90$, 91].

\section{Perspective}

During the past 10 years, the studies on lipid-lowering therapy with Chinese herbs have achieved many progresses to some extent, but some limits are also existed: (1) although the effects of Xuezhikang (extract of red yeast rice) on lowering cholesterol and LDL-c were evidenced in multicenter, large sample, and randomized clinical trials $[66,92]$, most clinical trials on dyslipidemia with TCM did not show enough power to identify the definite effects due to small samples or unemployment of multicenter, large samples, and randomized design; (2) because of very complicated compounds contained in one herb, even in an extract of one herb, it is a very tough work to clarify the mechanism of TCM for treating dyslipidemia and interaction with western medicines, which lead to some obstacles in clinical application in combination with statins or other chemical agents; and (3) due to different herb has different active compound and different property, which has been taken as Han (Cold), Re (Heat), Wen (Warm) and Liang (Cool) according to TCM theory, it is hard in clinical practice to optimize its benefit effects or reduce adverse effects for patients with hyperlipidemia.

Along with a long-term use of statins in combination with other hypolipidemic drugs or alone, the adverse reactions frequently occurred about statins at domestic or abroad. TCM has been widely used in China for more than 2000 years. Screening highly efficient hypolipidemic agents from TCM with fewer adverse effects has attracted more attention, and the mechanisms of TCM for hyperlipidemia become a hot topic in cardiovascular diseases research field recently.

As mentioned above, the TCM has some beneficial effects on the treatment of patients with dyslipidemia and has less adverse effects compared with chemical agents. The advantages and disadvantages of TCM, however, needed to be confirmed in the future clinical trials according to the concept of evidence based medicine. Along with the development of modern scientific techniques, which can be applied in the TCM studies, it is becoming easier to identify how many component one herb contained and which component is a main component for treating dyslipidemia. As we all know, the TCM was used in clinical practice in the formula manner and demonstrated that many formulas and herbs have some favorable effects for dyslipidemia. Therefore, to develop new agents with effectiveness and safety from TCM is a promising way for prevention and treatment of patients with dyslipidemia and even then with cardiovascular diseases. 


\section{Conflict of Interests}

The authors declare that there is no conflict of interests.

\section{Authors' Contribution}

Ming Guo and Yue Liu contributed equally to this paper and are cofirst authors.

\section{Acknowledgments}

This study was supported by the TCM Public Welfare Scientific Research Project, the State Administration of TCM of the People's Republic of China (no. 201007001), the National Science and Technology Major Projects for "Major New Drugs Innovation and Development" (no. 2009ZX09502031), the National Natural Science Foundation of China (no. 81030063), and Science and Technology Project of Beijing Traditional Chinese Medicine (no. JJ2013-66).

\section{References}

[1] D. Y. Hu and J. H. Wang, "The status of chinese prevention and treatment of dyslipidemia," Chinese Journal of Practical Internal Medicine, vol. 29, no. 1, pp. 2-3, 2009.

[2] N. J. Stone, J. Robinson, A. H. Lichtenstein et al., "2013 ACC/AHA guideline on the treatment of blood cholesterol to reduce atherosclerotic cardiovascular risk in adults: a report of the American college of cardiology/American heart association task force on practice guidelines," Circulation, 2013.

[3] J. M. McKenney, "Pharmacologic options for aggressive lowdensity lipoprotein cholesterol lowering: benefits versus risks," The American Journal of Cardiology, vol. 96, no. 4, pp. 60-66, 2005.

[4] J. G. Jiang, "The clinical study progress of Chinese herbal medicine for hyperlipidemia," Journal of Practical Traditional Chinese Medicine, vol. 24, no. 9, pp. 614-615, 2008.

[5] H. X. Shi and Q. H. Li, "Research progress of traditional Chinese medicine treatment of hyperlipidemia," Journal of Medical Forum, vol. 28, no. 10, pp. 123-124, 2007.

[6] Z. P. Xu, Z. J. Lu, J. H. Chen, X. Deng, Y. Mao, and X. Huo, "The effect of rhubarb ethanol-extract on hyperlipidemia and liver fatty in rabbits," Zhongguo Ying Yong Sheng Li Xue Za Zhi, vol. 23, no. 3, pp. 375-380, 2007.

[7] Q. Gao, W. S. Qin, Z. H. Jia et al., "Rhein improves renal lesion and ameliorates dyslipidemia in $\mathrm{db} / \mathrm{db}$ mice with diabetic nephropathy," Planta Medica, vol. 76, no. 1, pp. 27-33, 2010.

[8] Z. H. Xiong, "effect of rhubarb on lipid and TGF- $\beta 1$ level in patients with diabetic nephropathy," Journal of Hannan Medical University, vol. 18, no. 8, pp. 1066-1068, 2012.

[9] R. Zhou, L. Wang, X. Xu et al., "Danthron activates AMPactivated protein kinase and regulates lipid and glucose metabolism in vitro," Acta Pharmacologica Sinica, vol. 34, no. 8, pp. 1061-1069, 2013.

[10] Y. Li and Y. F. Liu, "research review of adverse effect of Rheum tanguticum," China Pharmacy, vol. 17, no. 9, pp. 710-712, 2006.

[11] T. You, The research on the damage of over dose Rhubarb to hepatocyte [M.S. thesis], Chinese Medical Sciences University, 2005.
[12] J. Du, L. N. Sun, W. W. Xing et al., "Lipid-lowering effects of polydatin from Polygonum cuspidatum in hyperlipidemic hamsters," Phytomedicine, vol. 16, no. 6-7, pp. 652-658, 2009.

[13] W. W. Xing, J. Z. Wu, M. Jia, J. Du, H. Zhang, and L. Qin, "Effects of polydatin from Polygonum cuspidatum on lipid profile in hyperlipidemic rabbits," Biomedicine and Pharmacotherapy, vol. 63, no. 7, pp. 457-462, 2009.

[14] C. S. Park, Y. C. Lee, J. D. Kim, H. Kim, and C. Kim, "Inhibitory effects of Polygonum cuspidatum water extract (PCWE) and its component rasveratrol on acyl-coenzyme A-cholesterol acyltransferase activity for cholesteryl ester synthesis in HepG2 cells," Vascular Pharmacology, vol. 40, no. 6, pp. 279-284, 2004.

[15] L. Zhu, X. Luo, and Z. Jin, "Effect of resveratrol on serum and liver lipid profile and antioxidant activity in hyperlipidemia rats," Asian-Australasian Journal of Animal Sciences, vol. 21, no. 6, pp. 890-895, 2008.

[16] L. P. Tong, "Oral Polygonum cuspidatum decoction to gastrointestinal adverse reaction in one case," Lishizhen Medicine and Materia Medica Research, vol. 13, no. 5, p. 277, 2002.

[17] J. Chen, H. Zhao, Y. Yang, B. Liu, J. Ni, and W. Wang, "Lipid-lowering and antioxidant activities of Jiang-Zhi-Ning in Traditional Chinese Medicine," Journal of Ethnopharmacology, vol. 134, no. 3, pp. 919-930, 2011.

[18] Z. H. Lin and Y. Xiong, "Effects of cassia seeds on blood fat of rats with hyperlipemia," The New Journal of Traditional Chinese Medicine, vol. 42, no. 7111, 112 pages, 2010.

[19] H. B. Li, K. Y. Fang, C. T. Lu, and X. Li, "Study on lipidregulating function for the extracts and their prescriptions from semen cassiae and fructus crataegi," Zhong Yao Cai, vol. 30, no. 5, pp. 573-575, 2007.

[20] X. Luo, X. Xu, C. Huang et al., "Experiment study of total anthraquinone in cassiae semen on lipid peroxidation and PPAR- $\gamma$ expression in liver tissues of rats with alcoholic fatty liver," Zhongguo Zhong Yao Za Zhi, vol. 36, no. 12, pp. 1654-1659, 2011.

[21] Y. Y. Zou and J. S. Li, "Analysis of the potential satety risk of semen cassiae-containing health foods," Food Science and Technology, vol. 34, no. 5, pp. 295-297, 2009.

[22] J. Y. Zhou, S. W. Zhou, K. B. Zhang et al., "Chronic effects of berberine on blood, liver glucolipid metabolism and liver PPARs expression in diabetic hyperlipidemic rats," Biological and Pharmaceutical Bulletin, vol. 31, no. 6, pp. 1169-1176, 2008.

[23] X. X. Chang, H. M. Yan, Q. Xu et al., "The effects of berberine on hyperhomocysteinemia and hyperlipidemia in rats fed with a long-term high-fat diet," Lipids in Health and Disease, vol. 11, article 86, 2012.

[24] Y. Hu, E. A. Ehli, J. Kittelsrud et al., "Lipid-lowering effect of berberine in human subjects and rats," Phytomedicine, vol. 19, no. 10, pp. 861-867, 2012.

[25] Z. Liu, X. Zhou, P. Su et al., "Experimental study of total flavonoids from stem-leaf of Scutellaria Baicalensis in treating type 2 diabetic hyperlipidemia," Traditional Chinese Drug Research and Clinical Pharmacology, vol. 20, no. 1, pp. 5-7, 2009.

[26] S. Megalli, N. M. Davies, and B. D. Roufogalis, "Antihyperlipidemic and hypoglycemic effects of Gynostemma pentaphyllum in the Zucker fatty rat," Journal of Pharmacy and Pharmaceutical Sciences, vol. 9, no. 3, pp. 281-291, 2006.

[27] L. Zhou, Y. P. Xu, Y. Wei, X. P. Shi, and C. P. Liu, "The effect of Gynostemma pentaphyllum (GP) on plasma lipoprotein metabolism and lipoperoxidation lipoprotein in the experimental hyperglycemia rats," Zhongguo Ying Yong Sheng Li Xue Za Zhi, vol. 24, no. 2, pp. 205-208, 2008. 
[28] Z. Y. Deng, S. M. Zhu, D. Wang et al., "Effect of Puerarin on lipidemia, blood coagulation and platelet aggregation in hyperlipidemia rats," Chinese Journal of Modern Applied Pharmacy, vol. 28, no. 7, pp. 611-614, 2011.

[29] J. Wang, Y. Guo, J. Niu, J. Liu, L. Wang, and P. Li, "Effects of Radix Puerariae flavones on liver lipid metabolism in ovariectomized rats," World Journal of Gastroenterology, vol. 10, no. 13, pp. 1967-1970, 2004.

[30] J. P. Xiong, H. W. Guo, and X. F. Gu, "Study on effect of hawthorn fruit extraction on human blood lipids," Chinese Journal of Public Health, vol. 20, no. 12, pp. 1469-1470, 2004.

[31] C. Kwok, C. Li, H. Cheng et al., "Cholesterol lowering and vascular protective effects of ethanolic extract of dried fruit of Crataegus pinnatifida, hawthorn (Shan Zha), in diet-induced hypercholesterolaemic rat model," Journal of Functional Foods, vol. 5, no. 3, pp. 1326-1335, 2013.

[32] C. Lin, T. Li, and M. Lai, "Efficacy and safety of Monascus purpureus Went rice in subjects with hyperlipidemia," European Journal of Endocrinology, vol. 153, no. 5, pp. 679-686, 2005.

[33] O. Gheith, H. Sheashaa, M. Abdelsalam, Z. Shoeir, and M. Sobh, "Efficacy and safety of Monascus purpureus Went rice in children and young adults with secondary hyperlipidemia: a preliminary report," European Journal of Internal Medicine, vol. 20, no. 3, pp. e57-e61, 2009.

[34] F. Jiang, J. Qian, S. Chen, W. Zhang, and C. Liu, "Ligustrazine improves atherosclerosis in rat via attenuation of oxidative stress," Pharmaceutical Biology, vol. 49, no. 8, pp. 856-863, 2011.

[35] G. F. Wang, C. G. Shi, M. Z. Sun et al., "Tetramethylpyrazine attenuates atherosclerosis development and protects endothelial cells from ox-LDL," Cardiovascular Drugs and Therapy, vol. 27, no. 3, pp. 199-210, 2013.

[36] W. Ji and B. Q. Gong, "Hypolipidemic activity and mechanism of purified herbal extract of Salvia miltiorrhiza in hyperlipidemic rats," Journal of Ethnopharmacology, vol. 119, no. 2, pp. 291-298, 2008.

[37] S. M. Li, Y. P. Li, and H. Huang, "The effects of tanshinone IIA sulfonate on hemorheology and blood lipid in patients with diabetes mellitus," Journal of Clinical Rational Drug Use, vol. 4, pp. 8-9, 2011.

[38] E. Jang, M. Choi, U. J. Jung et al., "Beneficial effects of curcumin on hyperlipidemia and insulin resistance in highfat-fed hamsters," Metabolism, vol. 57, no. 11, pp. 1576-1583, 2008.

[39] J. B. Di, Z. L. Gu, X. D. Zhao et al., "Research on curcumin for the prevention and control of fatty liver in rats," Chinese Traditional and Herbal Drugs, vol. 19, no. 8, pp. 1322-1326, 2010.

[40] H. E. Xiong-Wei, "The clinical control study on the effect of rhizoma alismatis on blood fat in health volunteers," Journal of Chongqing Medical University, vol. 34, no. 3, pp. 376-378, 2009.

[41] S. Z. Li, Z. J. Jin, and S. Y. Zhang, "The effects of alisma orientalis's extracts on blood lipid and antioxidation of experimental hyperlipidemia mice," China Practical Medicine, vol. 332, pp. 79, 2008.

[42] Y. P. Zhao, L. Lu, Y. F. Zhang et al., "Study on discriminating nephrotoxic components in zexie," China Journal of Chinese Materia Medica, vol. 36, no. 6, pp. 758-761, 2011.

[43] S. M. Wang, G. L. Yang, H. Y. Dai et al., "Effect of plantain seed on the lipid peroxidation in rats with hyperlipidemia," Zhongguo Zuzhi Gongcheng Yanjiu yu Linchuang Kangfu, vol. 10, no. 19, pp. 184-186, 2006.
[44] A. L. Romero, K. L. West, T. Zern, and M. L. Fernandez, "The seeds from Plantago ovata lower plasma lipids by altering hepatic and bile acid metabolism in guinea pigs," Journal of Nutrition, vol. 132, no. 6, pp. 1194-1198, 2002.

[45] H. Du, J. You, X. Zhao, J. Park, S. Kim, and K. Chang, "Antiobesity and hypolipidemic effects of lotus leaf hot water extract with taurine supplementation in rats fed a high fat diet," Journal of Biomedical Science, vol. 17, supplement 1, article S42, 2010.

[46] T. Zhou, D. Luo, X. Li, and Y. Luo, "Hypoglycemic and hypolipidemic effects of flavonoids from lotus (Nelumbo nuficera Gaertn) leaf in diabetic mice," Journal of Medicinal Plant Research, vol. 3, no. 4, pp. 290-293, 2009.

[47] C. Wu, M. Yang, K. Chan, P. Chung, T. Ou, and C. Wang, "Improvement in high-fat diet-induced obesity and body fat accumulation by a nelumbo nucifera leaf flavonoid-rich extract in mice," Journal of Agricultural and Food Chemistry, vol. 58, no. 11, pp. 7075-7081, 2010.

[48] Y. B. Qiu, J. Liu, and F. Wu, "Research on chemical compositions and pharmacology role of Astragalus," Chinese Journal of Convalescent Medicine, vol. 20, no. 5, pp. 435-436, 2011.

[49] Y. H. Wang, J. G. Qin, W. Q. Guo et al., "Expermiental study of ginsenoside on inhibiting hyperlipemia and atherosclerosis," Chinese Archives of Traditional Chinese Medicine, vol. 24, no. 3, pp. 429-430, 2006.

[50] X. M. Zhang, S. C. Qu, D. Y. Sui, X. Yu, and Z. Lv, "Effects of ginsenoside- $\mathrm{Rb}$ on blood lipid metabolism and anti-oxidation in hyperlipidemia rats," Zhongguo Zhong Yao Za Zhi, vol. 29, no. 11, pp. 1085-1088, 2004.

[51] X. Congkun, W. Rui, and Y. Zhifang, "Study on effect of Polygonum mutiflorum extract on lipid metabolism and its anti-oxidation in SD rats with hyperlipemia," China Pharmaceuticals, vol. 18, no. 24, pp. 19-20, 2009.

[52] C. Wang, L. Zhang, Z. Yuan, Y. Jin, and Z. Zhang, "Blood lipid regulation of ethyl acetate extracting fraction and stilbene glycoside from tuber of Polygonum multiflorum," Chinese Traditional and Herbal Drugs, vol. 39, no. 1, pp. 78-83, 2008.

[53] H. Dong, Y. Zhao, L. Zhao, and F. Lu, "The effects of berberine on blood lipids: a systemic review and meta-analysis of randomized controlled trials," Planta Medica, vol. 79, no. 6, pp. 437-446, 2013.

[54] Z. Y. Lei, "The medical security of Rhizoma coptidis and berberine," China Pharmaceuticals, vol. 19, no. 9, pp. 84-85, 2010.

[55] X. L. Li and L. Tong, "The study progress of chemical components and pharmacological role of Scutellaria baicalensis stem leaf," Journal of Chengde Medical College, vol. 23, no. 3, pp. 284286, 2006.

[56] B. Regulska-Ilow, J. Biernat, H. Grajeta, R. Ilow, and M. Drzewicka, "Influence of bioflavonoids from the radix extract of Scutellaria baicalensis on the level of serum lipids, and the development of laboratory rats fed with fresh and oxidized fats," Nahrung, vol. 48, no. 2, pp. 123-128, 2004.

[57] C. L. You, P. Q. Su, and X. X. Zhou, "Study on effect and mechanism of Scutellaria baicalensis stem-leaf total flavonoid in regulating lipid metabolism," Zhongguo Zhong Yao Za Zhi, vol. 33, no. 9, pp. 1064-1066, 2008.

[58] X. L. Pu and Q. Wu, "Progressive study on Gynostemma pentaphyllum," Lishizhen Medicine and Materia Medica Research, vol. 21, no. 7, pp. 1758-1760, 2010.

[59] S. Megalli, F. Aktan, N. M. Davies, and B. D. Roufogalis, "Phytopreventive anti-hyperlipidemic effects of Gynostemma 
pentaphyllum in rats," Journal of Pharmacy and Pharmaceutical Sciences, vol. 8, no. 3, pp. 507-515, 2005.

[60] C. Müller, A. Gardemann, G. Keilhoff, D. Peter, I. Wiswedel, and L. Schild, "Prevention of free fatty acid-induced lipid accumulation, oxidative stress, and cell death in primary hepatocyte cultures by a Gynostemma pentaphyllum extract," Phytomedicine, vol. 19, no. 5, pp. 395-401, 2012.

[61] D. H. Zhang, Q. B. Dong, and S. G. Peng, "Chemical componets, pharmacologic actions and clinical study of Radix Puerariae," Captical Medicine, no. 12, pp. 44-45, 2007.

[62] L. P. Yan, S. W. Chan, A. S. Chan, S. Chen, X. Ma, and H. $\mathrm{Xu}$, "Puerarin decreases serum total cholesterol and enhances thoracic aorta endothelial nitric oxide synthase expression in diet-induced hypercholesterolemic rats," Life Sciences, vol. 79, no. 4, pp. 324-330, 2006.

[63] W. Xie, Y. Zhao, and L. Du, "Emerging approaches of traditional Chinese medicine formulas for the treatment of hyperlipidemia," Journal of Ethnopharmacology, vol. 140, no. 2, pp. 345367, 2012.

[64] Y. Lin, M. A. Vermeer, and E. A. Trautwein, “Triterpenic acids present in hawthorn lower plasma cholesterol by inhibiting intestinal ACAT activity in hamsters," Evidence-based Complementary and Alternative Medicine, vol. 2011, Article ID 801272, 9 pages, 2011.

[65] C. Niu, C. Chen, L. Chen, K. Cheng, C. Yeh, and J. Cheng, "Decrease of blood lipids induced by Shan-Zha (fruit of Crataegus pinnatifida) is mainly related to an increase of PPAR in liver of mice fed high-fat diet," Hormone and Metabolic Research, vol. 43, no. 9, pp. 625-630, 2011.

[66] Q. Shang, Z. Liu, K. Chen, H. Xu, and J. Liu, "A systematic review of xuezhikang, an extract from red yeast rice, for coronary heart disease complicated by dyslipidemia," Evidence-Based Complementary and Alternative Medicine, vol. 2012, Article ID 636547, 18 pages, 2012.

[67] H. P. M. Kumari, K. A. Naidu, S. Vishwanatha, K. Narasimhamurthy, and G. Vijayalakshmi, "Safety evaluation of Monascus purpureus red mould rice in albino rats," Food and Chemical Toxicology, vol. 47, no. 8, pp. 1739-1746, 2009.

[68] B. Shu, C. J. Zhou, Y. H. Ma, Y. Wang, and Q. Shi, "Research progress on pharmacological activities of the available compositions in Chinese medicinal herb Ligusticum chuanxiong," Chinese Pharmacological Bulletin, vol. 22, no. 9, pp. 1043-1047, 2006.

[69] L. Y. Xia, Modern Toxicology of Chinese Materia Medica, Tianjin Science and Technology Translation \& Publishing Corporation, 2005.

[70] A. L. Liu, M. Y. Lee, and Y. T. Wang, "Research progress on active principles from Salvia miltiorrhizae," Chinese Pharmaceutical Journal, vol. 42, no. 9, pp. 641-646, 2007.

[71] Y. Kang, U. Jin, H. Chang et al., "Inhibition of microsomal triglyceride transfer protein expression and atherogenic risk factor apolipoprotein B100 secretion by tanshinone IIA in HepG2 cells," Phytotherapy Research, vol. 22, no. 12, pp. 1640$1645,2008$.

[72] J. R. Li and D. H. Zheng, "Research study on pharmacologic action and advese effect of Salvia miltiorrhiza," Chinese Journal of Ethnomedicine and Ethnopharmacy, vol. 19, no. 24, p. 31, 2010.

[73] C. Y. Liu, "Chemical constituents of Curcuma longa L.," Shenyang Pharmaceutical University, 2008.

[74] M. M. Mahfouz, Q. Zhou, and A. F. Kummerow, "Effect of curcumin on LDL oxidation in vitro, and lipid peroxidation and antioxidant enzymes in cholesterol fed rabbits," International Journal for Vitamin and Nutrition Research, vol. 81, no. 6, pp. 378-391, 2011.

[75] X. B. Dou, X. D. Wo, C. L. Fan et al., "Effect of curcumin on the expression of low density lipoprotein receptor in HepG2 cell line," Chinese Pharmaceutical Journal, vol. 42, no. 8, pp. 572-575, 2007.

[76] C. W. Li and S. S. Wu, "The research progress of rhizoma alismatis on regulating blood lipids," Asia-Pacific Traditional Medicine, vol. 5, no. 10, pp. 152-153, 2009.

[77] C. Xiong, N. Wang, S. M. Wang et al., "The study on the general pharmacology of polysaccharides from semen plantaginis," Journal of Bethune Military Medical College, vol. 6, no. 4, pp. 196-198, 2008.

[78] R. Solà, E. Bruckert, R. Valls et al., "Soluble fibre (Plantago ovata husk) reduces plasma low-density lipoprotein (LDL) cholesterol, triglycerides, insulin, oxidised LDL and systolic blood pressure in hypercholesterolaemic patients: A randomised trial," Atherosclerosis, vol. 211, no. 2, pp. 630-637, 2010.

[79] F. G. Wang, J. Cao, B. Liu et al., "The chemical composition of lotus leaf and its pharmacological action research progress," Lishizhen Medicine and Materia Medica Research, vol. 21, no. 9, pp. 2339-2340, 2010.

[80] M. Jiangwei, Q. Zengyong, and X. Xia, "Aqueous extract of Astragalus mongholicus ameliorates high cholesterol diet induced oxidative injury in experimental rats models," Journal of Medicinal Plant Research, vol. 5, no. 5, pp. 855-858, 2011.

[81] X. Yang, L. P. Jiang, and S. Wang, "Effect of polysaccharides from Astragalus on blood lipid, immune function and oxidative stress in hyperlipidemic rats," Research and Practice on Chinese Medicines, vol. 26, no. 5, pp. 37-40, 2012.

[82] Y. J. Cheng, "The regulation of Astragalus polysaccharide on plasma cholesterol and its mechanism in hyperlipidemia rats," Sun Yat-sen University, 2010.

[83] Y. Wang, L. P. Guo, H. C. Shang et al., "Literature analysis on 560 cases of adverse drug reactions/events of Astragalus injection," Journal of Traditional Chinese Medicine, vol. 52, no. 9, pp. 37-40, 2011.

[84] Y. Li, T. J. Zhang, S. X. Liu et al., "Research on chemical compositions and pharmacology role of Gingeng," Chinese Traditional and Herbal Drugs, vol. 40, no. 1, pp. 164-166, 2009.

[85] L. P. Christensen, "Chapter 1 ginsenosides: chemistry, biosynthesis, analysis, and potential health effects," Advances in Food and Nutrition Research, vol. 55, pp. 1-99, 2008.

[86] D. Y. Kim, H. D. Yuan, I. K. Chung, and S. H. Chung, "Compound k, intestinal metabolite of ginsenoside, attenuates hepatic lipid accumulation via AMPK Activation in human hepatoma cells," Journal of Agricultural and Food Chemistry, vol. 57, no. 4, pp. 1532-1537, 2009.

[87] X. S. Zhang and Q. L. Liu, “The reasearch progress of hypolipidemic and anti-atherosclerosis roles of Polygonum multiflorum," International Medicine and Health Guidance News, vol. 13, no. 16, pp. 155-157, 2007.

[88] X. Han, C. A. Wu, W. Wang et al., "mechanism research of stibene glucoside from Polygonum multiflorum," Chinese Archives of Traditional Chinese Medicine, vol. 26, no. 8, pp. 16871689, 2008.

[89] N. Li, Z. Chen, X. Mao, J. Yu, and R. Zhao, "Effects of lipid regulation using raw and processed radix polygoni multiflori in rats fed a high-fat diet," Evidence-Based Complementary and Alternative Medicine, vol. 2012, Article ID 329171, 10 pages, 2012. 
[90] P. F. Wei, X. Q. Hu, and A. J. Yan, "The adverse response of Polygonum multiflorum," Shaanxi Journal of Traditional Chinese Medicine, vol. 25, no. 2, pp. 170-171, 2004.

[91] S. H. Wang, "The summary on adverse reactions of Polygonum multiflorum," Journal of Practical Traditional Chinese Medicine, vol. 19, no. 3, p. 163, 2003.

[92] Y. Feng, H. Xu, and K. Chen, "Natural polypill Xuezhikang: its clinical benefit and potential multicomponent synergistic mechanisms of action in cardiovascular disease and other chronic conditions," Journal of Alternative and Complementary Medicine, vol. 18, no. 4, pp. 318-328, 2012. 


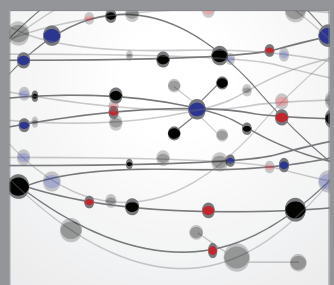

The Scientific World Journal
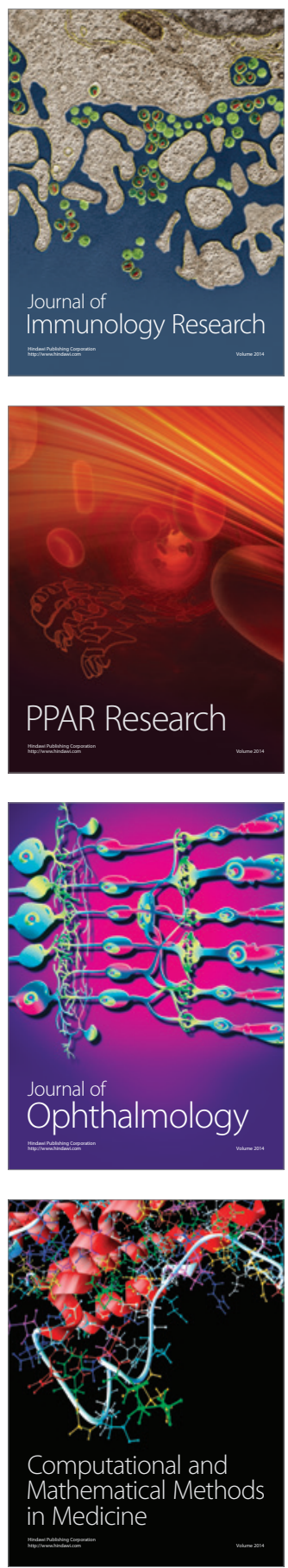

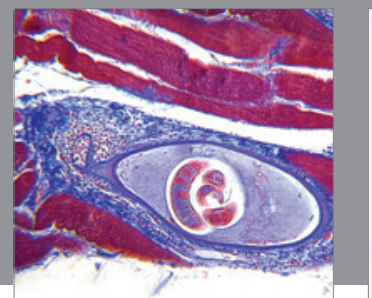

Gastroenterology

Research and Practice
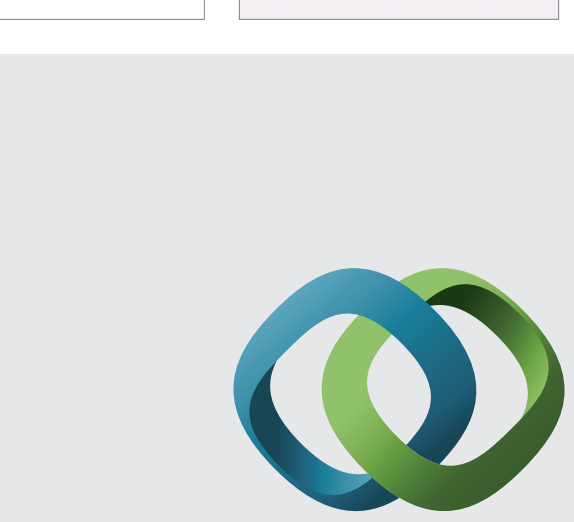

\section{Hindawi}

Submit your manuscripts at

http://www.hindawi.com
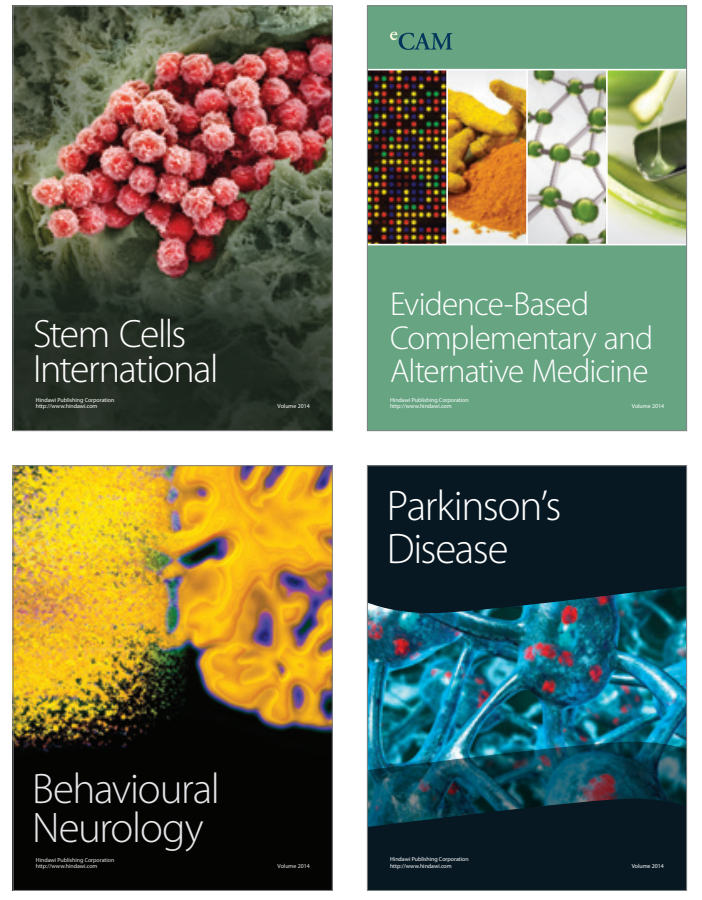
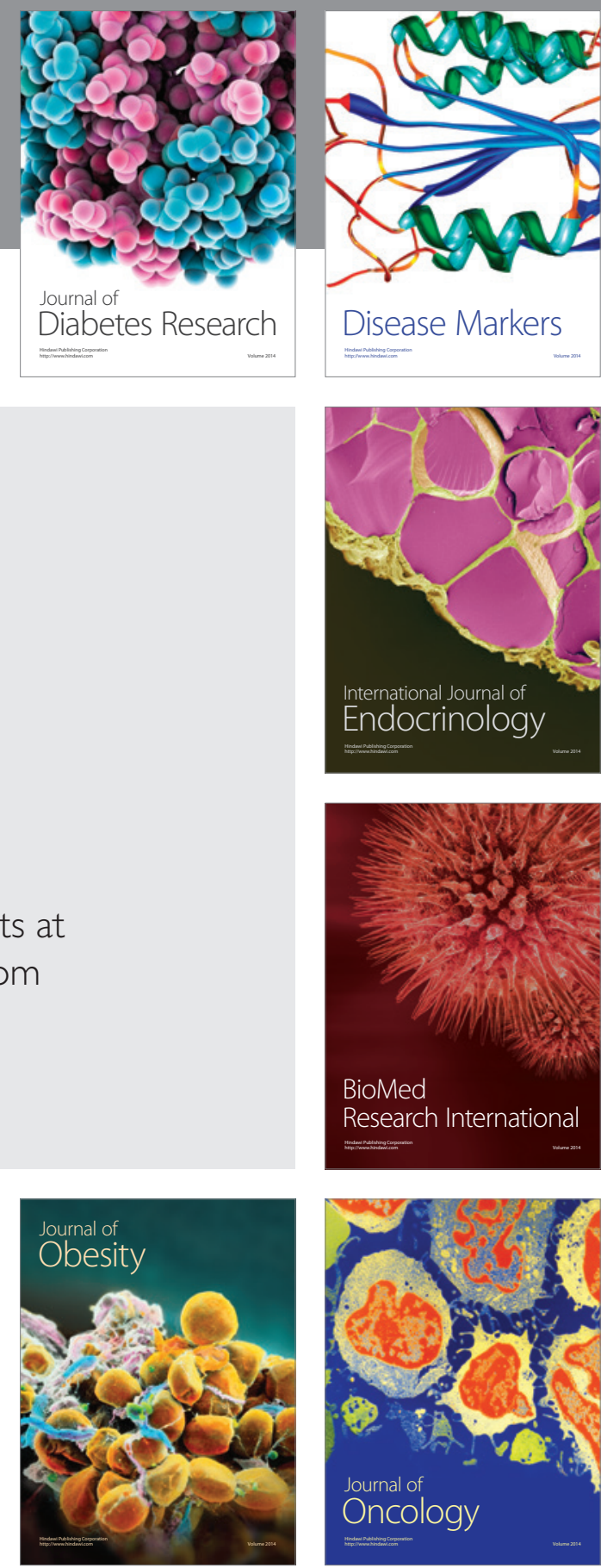

Disease Markers
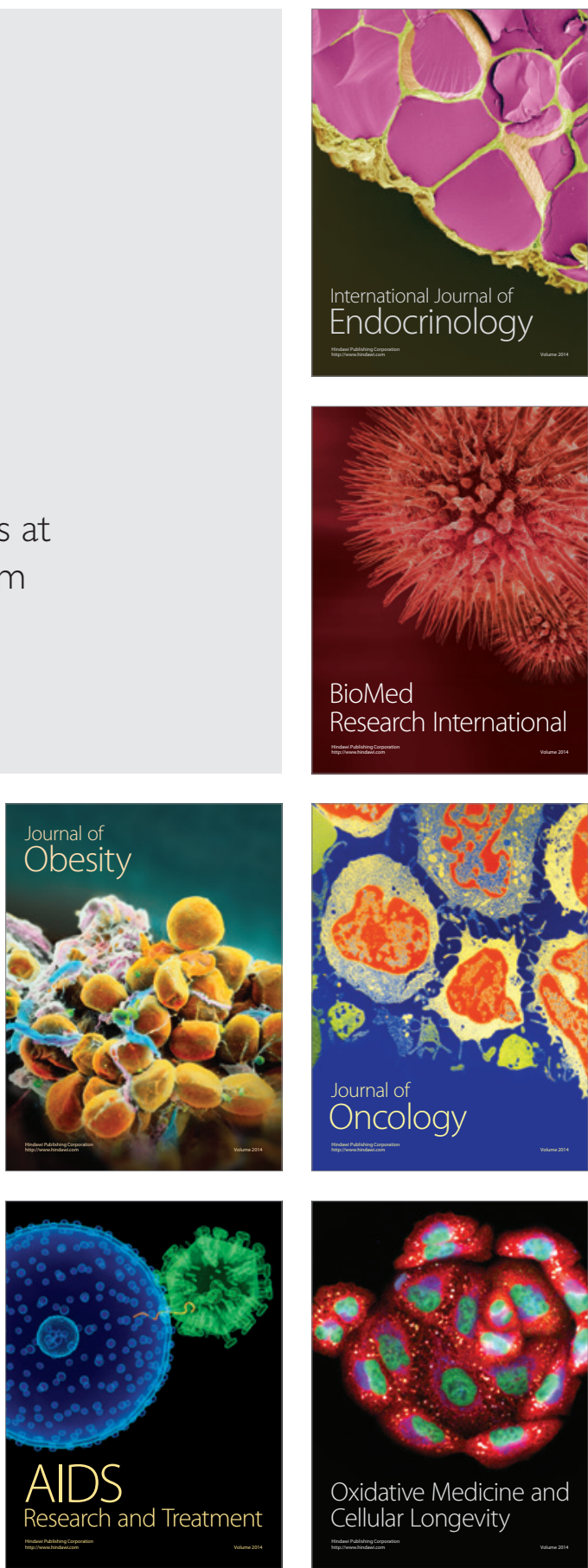